\title{
ObSERVED DISPARITY ON SCHISTOSOME INFECTION RATES IN FIELD BIOMPHALARIA PFEIFFERI (KRAUSS) between two areas of the Jos Metropolis, Nigeria
}

\author{
AKUFONGWE P.F.*, DONDJI B. ${ }^{*}$, OKWUOSA V.N.*, DAKUL D.A.* \& NTONIFOR H.N.*
}

\section{Summary :}

Two regions of the Jos Metropolis in Plateau State, Nigeria, with contrasting topographic features and harbouring many snails infested water bodies, were surveyed for the presence of cercariae shedding Biomphalaria pfeifferi (Krauss) for a period of 12 months. A significantly marked $(P<0.01)$ fluctuation in infection rates in field $B$. pfeifferi was observed between the two areas. The factors contributing to the disparity in shedding capacities are linked to human behavioural pattern, and the drying up of water bodies. Their importance with respect to the control of intestinal schistosomiasis in the region are discussed.

KEY WORDS : Biomphalaria pfeifferi. Schistosoma mansoni. cercariae.

\section{INTRODUCTION}

chistosomiasis is endemic in Nigeria with an estimated 11 million Nigerians infected (Iarotski \& Davis, 1981). Several isolated studies on the prevalence of the disease in Nigeria have been reported following the extensive survey by Ramsay (1935) of the former Northern Nigeria. Cowper (1963) reported urinary schistosomiasis infection rates of up to 95 per cent in some Northern districts where haematuria at or about puberty in boys was regarded as normal. Surveys on the Jos Plateau yielded infection rates of over 50 per cent for urinary schistosomiasis (Cowper, 1963).

In the Jos Plateau, Schistosoma mansoni infection rates ranging from 8 per cent at Panyam to 28 per cent in Jos were reported by Cowper (1963). Akoh (1980), in a survey of rural school children in the Plateau, recorded a prevalence rate of 12.3 per cent. Most recently, Dabit (personal communication), in a study carried out in 1992 in some primary schools in Jos, observed a 35.5 per cent prevalence rate for $S$. mansoni and 22.4 per cent for $S$. haematobium. The incidence of the disease is possibly on the rise especially with the construction of many water development projects. Transmission is very focal in some areas, generally

* Department of Zoology, Applied Entomology and Parasitology Unit, University of Jos, Nigeria.

Correspondence : Akufongwe Peter Fru, c/o P. O. Box 835, Jos, Plateau State, Nigeria.
Résumé : DifFÉRENCE REMARQUABLE DU TAUX D'INFESTATION EN SCHISTOSOME DU MOLLUSQUE BIOMPHALARIA PFEIFFERI (KRAUSS) ENTRE DEUX réGIONS DE LA métropole urbaine de Jos, Nigéria

Deux régions à topographie différente de la métropole urbaine de Jos ont été explorées pendant 12 mois en vue du dénombrement des mollusques Biomphalaria pfeifferi infestés par Schistosoma mansoni. Une différence importante $(P<0.01)$ a éte notée entre les taux d'infection des mollusques collectés dans les deux zones. Les facteurs responsables de cette différence sont liés au comportement humain et à l'assèchement des collections d'eau au cours de la saison sèche. Leur importance quant au contrôle de la bilharziose intestinale dans la région a été discutée par les auteurs.

MOTS CLES : Biomphalaria pfeifferi. Schistosoma mansoni. cercaires.

influenced by local transmission characteristics. New studies are encouraged not only to identify new endemic foci, but also peculiar socio-cultural and ecological factors influencing transmission. Such data could be very valuable in planning molluscicidal and/or chemotherapeutic control of transmission.

\section{MATERIALS AND METHODS}

$\sqrt{1}$ he work was carried out between June 1992 and May 1993 in two areas of the Jos Metropolis, in the Plateau State, Nigeria where B. pfeifferi is the incriminated intermediate host of Schistosoma mansoni. The Farigada and students' village and the abattoir areas are about $10 \mathrm{~km}$ apart. The two areas have contrasting topography, harbour many snail habitats like small ponds, man-made drains, burrow pits and a river each. Many active human activities are common in both areas.

A total of four ditches (temporary habitats) of approximately the same dimensions; two in each region and the rivers (permanent habitats) were selected for the study. B. pfeifferi were collected monthly during the morning hours using a flat collecting net of Okwuosa (1979) from the three sites within each region for a fixed time (3h). Collected snails were checked for cercarial shedding and the cercariae numbers estimated using the sub-sampling technique of Christensen et al. (1984). 


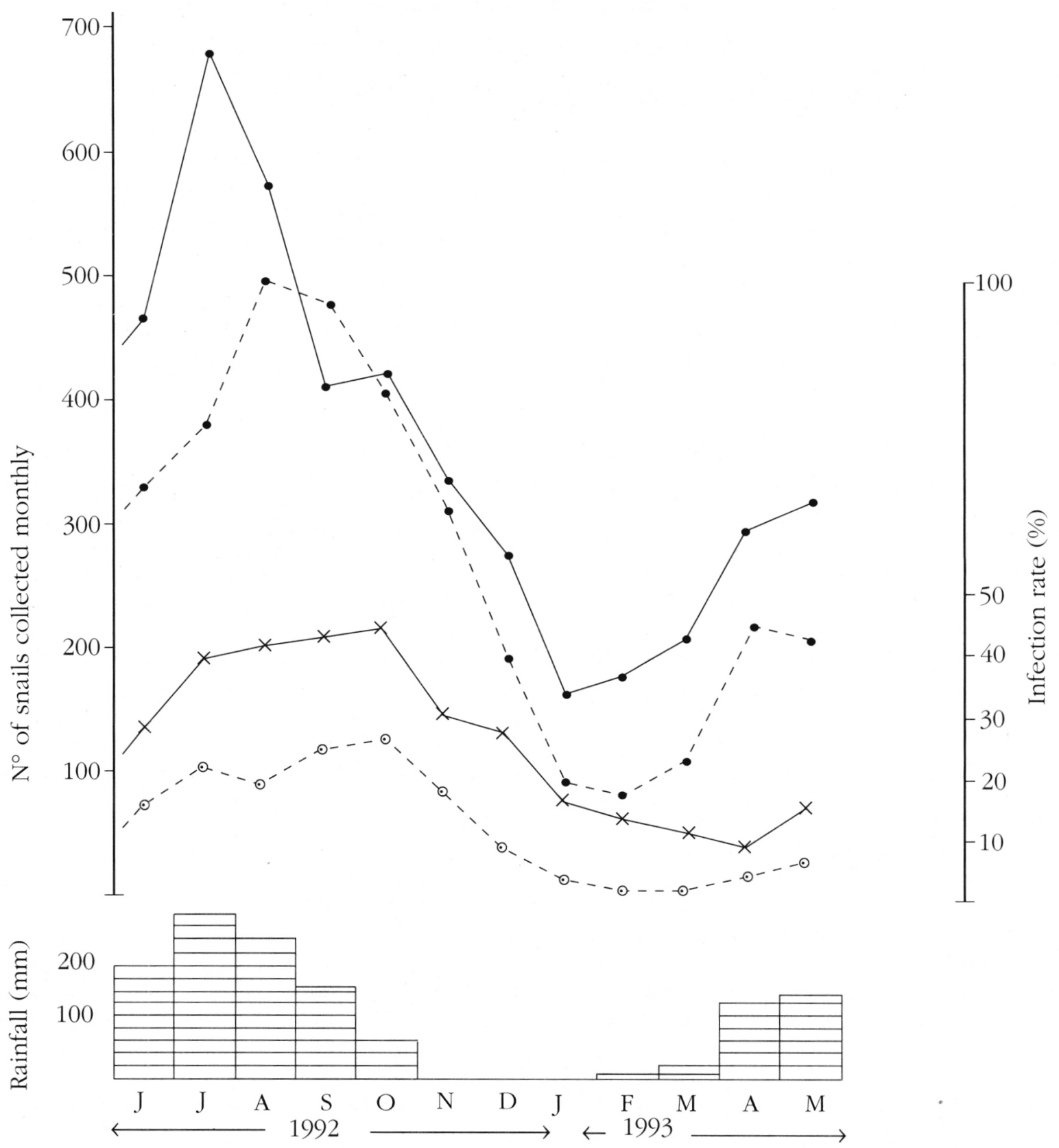

\footnotetext{
$\bullet \quad \mathrm{n}^{\circ}$ collected per 3 hours search at abattoir area

$\bullet-\bullet \quad n^{\circ}$ collected per 3 hours search at Farigada/Students' village area

$\varkappa \star \star x \quad$ infection rate in abattoir area

$\odot-\odot--\odot-\odot \quad$ infection rate in Farigada/Students' village area
}

Fig. 1. - Showing monthly fluctuation in the infection rate of B.pfeifferi as well as their relationship to rainfall in the study areas. 


\section{RESULTS}

statistically significant (Wilcoxon matched pairs signed ranks test, $\mathrm{P}<0.01$ ) and marked fluctuation in infection rates between the two regions (Fig. 1) was observed. There was a drastic fall of $32.86 \%$ in infection rate between October and November in the abattoir area and $49.85 \%$ in the Farigada and students' village area between November and December. A marked resurgence in infection rate was observed in both regions following the onset of the rainy season in April.

\section{DISCUSSION}

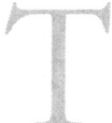

he significantly $(\mathrm{P}<0.01)$ marked disparity in infection rates noticed between the two areas is attributed to differences in terrain topography and human habits in both areas. The abattoir area is more hilly with huge rocks making the construction of toilet facilities very impracticable. This results to indiscriminate disposal of faeces contrary to the Farigada and students' village region which is a practically flat terrain and more or less an upper class residential area with adequate toilet facilities. The Muslims' ritual ablution of washing the anus with water after defaecation is a common practice in the abattoir area where defaecation along and sometimes in the river is common. When it rains, these excreta which are potential sources of infection are washed by surface run-off into the surrounding water bodies. This is a favourable pre-condition for egg hatching and consequently snail infection. This situation is much more facilitated in the abattoir region by virtue of its landscape.

The marked fall in infection rates and snail population noticed in November coincides with the dry season. While the temporary sites dried up, the rivers reduced to basically streaks of water. Parasitism coupled with the increasing harshness of weather conditions must have been responsible for the death of most of the infected snails leading to the sharp drop as similarly observed by Cridland (1958). The marked increase in infection rates in April when the snail population started building up a few weeks after the onset of rains in March is worth noting. This could possibly be attributed to snails that successfully went into diapause with a prepatent infection which attained patency shortly after the first rains that caused the snails to resume normal activities. Cooper et al. (1992) observed that almost all snails surviving diapause produced large numbers of cercariae once returned to water.
The possibility of a strain difference between B. pfeifferi from the two regions is unlikely because routine laboratory infection of snails from both regions showed equal susceptibility (Akufongwe et al., personal communication) Nevertheless, more sensitive biochemical analyses are suggested. It is imperative to consider the role of diapausing snails, terrain topography and human behavioural profiles before planning and/or executing molluscicidal programmes. Such a campaign just at the onset of the rains could have a double advantage : most snails could be reached as all those that underwent diapause resume activity. Secondly, water volume is still small enough; thus a control programme could be cost-effective.

\section{REFERENCES}

Акон J.L. The incidence of intestinal helminthiasis and schistosomiasis in rural school children in Jos Plateau. Nigerian Journal of Parasitology, 1980, 1, 158-160.

Christensen N.O., Gotsche G. \& Frandsen. Parasitological techniques for use in routine laboratory maintenance of schistosome and for use in studies on the epidemiology of human and bovine schistosomiasis. Danish Bilharziasis Laboratory Handbook, 1984, 40 p .

CoOper L.A., Richards C.S. \& LewIS F.A. Schistosoma mansoni infection in diapausing Biomphalaria glabrata snails : Studies of temperature and genetic influence on diapausing behaviour. American Journal of Tropical Medicine and Hygiene, 1992, 47 (4), 498-564.

Cowper S.G. Schistosomiasis in Nigeria. American Tropical Medicine and Parasitology, 1963, 57, 307-322.

CRIDland C.C. Ecological factors affecting the numbers of snails in a permanent stream. Journal of Tropical Medicine and Hygiene, 1958, 61, 16-20.

IAROTSKI I.A. \& DAVIS A. The schistosomiasis problem in the world : result of a W.H.O. questionnaire. Bulletin of the W.H.O., 1981, 59, 115-128.

OKwuOsa V.N. The ecological studies of freshwater snails with paricular reference to Schistosoma vectors in Lagos, Ogun States of Nigeria. Ph. D. Thesis University of Ibadan, Nigeria, 1979, 300 p.

RAMSAY G.W.ST.C. A study of schistosomiasis and certain other helminthic infections in Northern Nigeria. West African Medicine Journal, 1935, 8(2), part 4-6.

Accepté le 19 décembre 1994 